\title{
Expression of MIG/CXCL9 in Cystic Fibrosis and Modulation of Its Activities by Elastase of Pseudomonas aeruginosa
}

\author{
Sandra Jovic ${ }^{a}$ Medya Shikhagaie ${ }^{a}$ Matthias Mörgelin ${ }^{b}$ Sven Kjellström ${ }^{c}$ \\ Jonas Erjefalt ${ }^{a} \quad$ Anders I. Olin $^{\mathrm{a}, \mathrm{b}}$ Inga-Maria Frick ${ }^{\mathrm{b}} \quad$ Arne Egesten $^{\mathrm{a}}$ \\ Sections for a Respiratory Medicine and Allergology, and ${ }^{b}$ Infection Medicine, Department of Clinical Sciences, Lund \\ University, Skåne University Hospital, ' Department of Biochemistry and Structural Biology, Center for Molecular and \\ Protein Science, Institute for Chemistry and Chemical Engineering, Lund University, Lund, Sweden
}

\section{Key Words}

Cystic fibrosis · MIG/CXCL9 chemokine .

Pseudomonas aeruginosa $\cdot$ Host defense

\begin{abstract}
In cystic fibrosis (CF), colonization of the airways with Pseudomonas aeruginosa is associated with disease deterioration. The mechanism behind the disease progression is not fully understood. The present work shows that the antibacterial chemokine MIG/CXCL9 is present in the airways and in sputum of CF patients. MIG/CXCL9 showed high bactericidal activity against. $P$. aeruginosa, including some strains from the airways of CF patients. Full-length MIG/CXCL9 was detected in sputum from healthy controls and CF patients colonized with $P$. aeruginosa. However, degraded MIG/CXCL9 was only found in CF sputum. In vitro, elastase of $P$. aeruginosa cleaved off a fragment of similar size and two additional fragments from MIG/CXCL9. The fragments showed less bactericidal activity against $P$. aeruginosa compared with the full-length protein. The fragments did not activate the MIG/ CXCL9 receptor CXCR3 (expressed e.g. by NK cells, mast cells,
\end{abstract}

and activated T cells) but instead displayed noncompetitive inhibition. In vitro, a decrease in CXCR3-bearing cells was found within and in the proximity of the bronchial epithelium of CF lung tissue compared with controls. Taken together, both bactericidal and cell-recruiting activities of MIG/ CXCL9 are corrupted by $P$. aeruginosa through release of elastase, and this may contribute to impaired airway host defense in CF.

(c) 2014 S. Karger AG, Basel

\section{Introduction}

In cystic fibrosis (CF), impaired innate immune functions result in acquisition of chronic bacterial colonization of the airways, playing important roles in disease progression [1]. The underlying cause of CF is well known, i.e. a genetic defect in the cystic fibrosis transmembrane conductance regulator (CFTR). The normal product of this gene is an ion channel, which is expressed mainly in epithelial cells and blood cells. The CFTR is primarily responsible for balancing chloride, bicarbonate

\section{KARGER}

E-Mail karger@karger.com

www.karger.com/jin
(C) 2014 S. Karger AG, Basel

$1662-811 \mathrm{X} / 14 / 0066-0846 \$ 39.50 / 0$
Dr. Sandra Jovic

Section for Respiratory Medicine and Allergology Department of Clinical Sciences, Lund University BMC C14, Tornavägen 10, SE-221 84 Lund (Sweden) E-Mail Sandra.Jovic@med.lu.se 
and sodium transport across the airway epithelium, hence important for the airway surface liquid (ASL, the thin liquid lining the top of the airway epithelial cells) homeostasis. However, the mechanisms involved in causing a vulnerability to acquire infection, in particular with Pseudomonas aeruginosa have been less well elucidated [2, 3]. The majority of CF patients will eventually have their lungs colonized by $P$. aeruginosa, the most common pathogen associated with mortality in CF and once established, the infection is difficult to eradicate [1].

Antibacterial host defense proteins (HDPs) are an important arm of innate immunity. These proteins are present in the thin liquid layer, ASL on the airway epithelial cell surface. Some HDPs are constitutively expressed (e.g. lysozyme, lactoferrin, and SLPI) while the expression of others is induced by proinflammatory cytokines, in particular Th1 cytokines such as interferon- $\gamma$ [4]. In CF, there is a mixed inflammatory response, where colonization with $P$. aeruginosa skews inflammation from Th1, including Th1 and Th17 responses towards a Th2-driven inflammation $[5,6]$. There is an impaired bacterial killing in the ASL of CF patients, and both an increased content of salt and an altered depth of the ASL have been suggested as an underlying cause [7-10]. Furthermore, many HDPs, such as $\beta$-defensins, lose the bactericidal activity in the presence of salt $[11,12]$. Interestingly, it was recently shown in a porcine CFTR knockout model of CF that neither salt nor the depth of the periciliary liquid (that is part of the ASL) were affected, but instead a reduced $\mathrm{pH}$ of the ASL caused the impaired antibacterial activity of the HDPs investigated [13-15].

The chemokine MIG/CXCL9 (monokine induced by interferon- $\gamma$ ) is an ELR-negative CXC chemokine that has chemotactic and angiostatic properties. MIG/CXCL9 together with IP-10/CXCL10 and I-TAC/CXCL11, bind and activate the CXCR3 receptor, which is foremost expressed on NK cells, T cells, mast cells and endothelial cells. In addition, MIG/CXCL9 has defensin-like antimicrobial properties [16-18]. Furthermore, experimental data support important roles for MIG/CXCL9 in host defense of the airways. Thus, knockdown of MIG/CXCL9 expression using siRNA-technique significantly reduced the antibacterial activity at the epithelial cell surface in vitro. Also, in an animal model of airway infection, neutralizing antibodies against MIG/CXCL9, IP10/CXCL10, and I-TAC/CXCL11 resulted in reduced antimicrobial activity $[19,20]$.

In this study, we investigated bactericidal and receptor-activating properties of MIG/CXCL9 in relation to $P$. aeruginosa and its released elastase as seen in CF.

\section{Material and Methods}

\section{Special Reagents}

Recombinant human MIG/CXCL9, affinity-purified polyclonal antibodies against human MIG/CXCL9 and preimmune rabbit IgG were from PeproTech (London, UK). The synthetic peptides, LL-37, IST-66, IST-51, and LIKK-15 were made by Schafer-N (Copenhagen, Denmark). P. aeruginosa elastase was from Sigma-Aldrich (St Louis, Mich., USA). Fluo-4 AM and Fura Red were from Invitrogen (Stockholm, Sweden).

\section{Electron Microscopy}

Immunogold Labeling

Tissue samples from CF lung explants obtained during transplantation were fixed in PBS containing $4 \%$ paraformaldehyde with $0.1 \%$ glutaraldehyde and prepared for immunostaining and transmission electron microscopy as described [21]. In short, ultrathin sections were incubated with primary antibodies against MIG/CXCL9, followed by detection with a secondary goat anti rabbit antibody (conjugated with $10 \mathrm{~nm}$ colloidal gold; Electron Microscopy Sciences, Fort Washington, Pa., USA; diluted 1:10-1:20). Specimens were examined in a JEOL JEM 1230 transmission electron microscope (JEOL, Peabody, Mass., USA) at $60 \mathrm{kV}$ accelerating voltage. Images were recorded with a Gatan Multiscan 791 CCD camera.

\section{Scanning Electron Microscopy}

The $P$. aeruginosa strains PA01, 041E, 195B, and 308B were grown to mid-logarithmic phase and thereafter incubated with MIG/CXCL9 $(1 \mu \mathrm{M})$ or in buffer alone for $1 \mathrm{~h}$ at $37^{\circ} \mathrm{C}$. To verify bacterial killing, part of the samples were used for the viable count assay. The remaining parts of the samples were processed for scanning electron microscopy (SEM). In short, $10 \mu \mathrm{l}$ of the incubation mixture (undiluted) was mounted on poly-L-lysinecoated titanium discs, fixed in $2.5 \%$ (v/v) glutaraldehyde, $0.15 \mathrm{M}$ sodium cacodylate overnight at room temperature and then washed with $0.15 \mathrm{M}$ sodium cacodylate. After fixation, samples were washed and dehydrated in alcohol at increasing concentrations $(2 \times 15$ min per step), critical point dried, mounted on aluminum holders and covered with $20 \mathrm{~nm}$ of gold. Samples were examined in a XL 30 FEG scanning electron microscope operated at an acceleration voltage of $5 \mathrm{kV}$ and a magnification of $\times 5,000$.

\section{Isolates of $P$. aeruginosa}

The $P$. aeruginosa reference strain PA01 originally isolated from a wound and the clinical nonmucoid CF strains (022A, 032, 041E, 195B, and 308B) isolated from CF lungs were used in this study [22-24].

\section{Viable Counts Assay}

In the viable counts assay, bacteria were grown at $37^{\circ} \mathrm{C}, 5 \%$ $\mathrm{CO}_{2}$ to mid-logaritmic phase in Todd-Hewitt broth, then washed and diluted to a concentration of $1 \%\left(2 \times 10^{6} \mathrm{cfu} / \mathrm{ml}\right)$ in $10 \mathrm{mM}$ Tris ( $\mathrm{pH} 7.5,7.0$ and 6.5) containing $5 \mathrm{~mm}$ glucose (Tris-glucose) and different sodium chloride concentrations $(0,80$ and $160 \mathrm{mM})$. The bacteria were further diluted to a concentration of $\left(2 \times 10^{3}\right.$ $\mathrm{cfu} / \mathrm{ml}$ ) and $40 \mu \mathrm{l}$ of the bacteria suspension was incubated with protein of interest at different concentrations or in Tris-glucose buffer alone (control) at $37^{\circ} \mathrm{C}, 5 \% \mathrm{CO}_{2}$ for $1 \mathrm{~h}$. Thereafter, aliquots 
of the incubation were plated on agar in a series of dilutions to promote growth. If no colonies are formed, the bacteria have been killed [21].

\section{Sputum Samples}

Sputum samples were obtained from 5 CF patients colonized with $P$. aeruginosa. Induced sputum from three healthy individuals was obtained after inhalation of $5 \mathrm{ml}$ nebulized sodium chloride $(30 \mathrm{mg} / \mathrm{ml})$. All subjects gave their written informed consent to participate in the study, which was approved by the ethics committee in Lund (2011/434).

\section{SDS-PAGE and Western Blotting}

Recombinant human MIG/CXCL9, sputum from CF patients and healthy controls were separated on Tris-tricine gels. To visualize the peptides, Coomassie Brilliant Blue R-350 (GE Healthcare, Uppsala, Sweden) was used. For Western blot, the subsequent procedures were performed according to the instructions of the manufacturer (Bio-Rad, Hercules, Calif., USA).

\section{Modeling Predictive Structures of MIG/CXCL9}

A model structure of full-length MIG/CXCL9 (Q07325) was created on the basis of a theoretical model of MIG/CXCL9 as described $[19,25]$.

\section{Mass Spectrometry}

Coomassie-stained gel bands were washed with $40 \%$ (v/v) acetonitrile. Reduction was performed with $10 \mathrm{mM}$ dithiothreitol at $56^{\circ} \mathrm{C}$ for $30 \mathrm{~min}$, alkylation with $30 \mathrm{~mm}$ iodoacetamide at room temperature for $20 \mathrm{~min}$ (in dark) and digestion with Asp-N endopeptidase (Roche Diagnostics, Mannheim, Germany; $25 \mu \mathrm{g} / \mathrm{ml}$ ) in $25 \mathrm{mM}$ ammonium bicarbonate buffer ( $\mathrm{pH} 7.8$ ) for $16 \mathrm{~h}$ at $37^{\circ} \mathrm{C}$. After extraction of gel pieces with $75 \%$ acetonitrile in $5 \%$ TFA, peptides were subjected to reversed-phase HPLC separation (CapLC, Waters, Manchester, UK) and subsequent sequencing on a Q-TOF Ultima API ESI-MS/MS. In-solution digest of MIG/ CXCL9 fragments generated by $P$. aeruginosa elastase was analyzed by LC-MS/MS.

Automated N-terminal sequencing was performed using a Procise 494 instrument from Applied Biosystems as described [26].

\section{Cell Culture}

CXCR3 Transfectants

The murine 300-19 cell line transfected with human CXCR3 (kindly provided by Dr. Bernhard Moser) was grown in RPMI $1640 \mathrm{MeEtOH}$ and 2\% G418.

\section{Air Liquid Interface}

Primary human bronchial epithelial cells ( $3 \mathrm{H}$ Biomedical) were grown in BEGM supplemented with BEGM bullet kit $(3 \mathrm{H}$ Biomedicals) in a Transwell system (Corning HTS Transwell, 24well permeable support, Sigma; $0.4 \mu \mathrm{m}$ pore size, 12 -mm diameter, polyester).

The medium was changed every 2 nd day until the cells' apical $(0.5 \mathrm{ml})$ and basolateral sides $(1.5 \mathrm{ml})$ were filled with BEGM (supplemented with BEGM bullet kit). The medium on the apical side was removed at day 3 , and hereafter the cells were exposed to ambient conditions. On the basolateral side, ALI medium containing BEGM supplemented with bullet kit (3H Biomedical),
BSA $(1.5 \mathrm{mg} / \mathrm{ml})$ and D-MEM (Invitrogen) supplemented with $1 \%$ MEM-Na-Pyr and 1\% L-glutamine and 1\% MEM NEA (50/50 w/w; Invitrogen) supplemented with $0.1 \%$ RA (0.1 mM; Sigma), was changed every day. After 24 days in ALI culture, the cells were rinsed on the apical side with $100 \mu \mathrm{l}$ PBS. Thereafter, the cells were stimulated by interferon- $\gamma(100 \mathrm{U} / \mathrm{ml})$ for $24 \mathrm{~h}$. This was followed by rinsing with $100 \mu \mathrm{l}$ PBS on the apical side. The MIG/CXCL9 content was determined by ELISA (R\&D systems, Oxford, UK).

\section{Activation of CXCR3}

Calcium immobilization was measured as a ratio between Fluo4 AM NW and Fura Red by FACS. Briefly, $1 \times 10^{7}$ cells $/ \mathrm{ml}$ were loaded with Fluo-4 AM $(3 \mu \mathrm{M})$ and Fura Red $(6 \mu \mathrm{M})$ for $45 \mathrm{~min}$, $37^{\circ} \mathrm{C}$. The CXCR3 transfected cells were analyzed for intracellular $\mathrm{Ca}^{2+}$ mobilization after incubation with MIG/CXCL9, IP-10/ CXCL10, I-TAC/CXCL11, IST-66, IST-51, or LIKK-15. Relative fluorescence intensity ratio was measured with a BD LSR II flow cytometer (BD, Franklin Lakes, N.J., USA).

\section{Immunohistochemistry}

Lung tissue was obtained from CF lung explants during transplantation and from previously healthy patients undergoing surgery for lung cancer (ethical approval LU412-03). Tissue samples were placed in $4 \%$ buffered formaldehyde immediately after surgical removal. After dehydration and paraffin embedding, 3- $\mu \mathrm{m}$ sections were generated from the tissue blocks. After rehydration and antigen retrieval, mouse monoclonal antibodies against CXCR3 (R\&D Systems, London, UK) were applied, and bound antibodies were detected using horseradish peroxidase-conjugated secondary goat antirabbit or goat anti-mouse antibodies (Sigma-Aldrich) and visualized using 3,3-diaminobenzidine as chromogen.

\section{Proteolysis and SDS-PAGE}

Five micrograms of MIG/CXCL9, IP-10/CXCL10 and I-TAC/ CXCL11 were incubated with $P$. aeruginosa elastase $(0.5$ and 0.8 $\mu \mathrm{g}$ ) or in PBS alone for $18 \mathrm{~h}$ at $37^{\circ} \mathrm{C}$. Also, $5 \mu \mathrm{g}$ of MIG/CXCL9 was incubated with neutrophil elastase $(0.5 \mu \mathrm{g})$, cathepsin $\mathrm{G}(0.5$ $\mu \mathrm{g})$, proteinase $3(0.5 \mu \mathrm{g})$ or in $\mathrm{PBS}$ alone for $18 \mathrm{~h}$ at $37^{\circ} \mathrm{C}$. After separation by SDS-PAGE, the peptides were visualized by Coomassie staining.

\section{Statistics}

Statistical analysis was performed using GraphPad Prism v6 (GraphPad Software, La Jolla, Calif., USA). The tests used were two-way ANOVA followed by Tukey's multiple comparison test and the Mann-Whitney $U$ test for unpaired samples when comparing separate groups. A p value $<0.05$ was considered significant $\left({ }^{*} \mathrm{p}<0.05\right.$ * $^{* *} \mathrm{p}<0.01$ * $\left.^{* * *} \mathrm{p}<0.001\right)$.

\section{Results}

\section{Distribution of MIG/CXCL9 in CF Lung}

Immunoelectron microscopy was performed on lung tissue obtained from individuals undergoing lung transplantation for end-stage $\mathrm{CF}$, to investigate the distribu- 
Table 1. Characteristics of patients with CF and controls

\begin{tabular}{|c|c|c|}
\hline & Controls $(\mathrm{n}=8)$ & $\mathrm{CF}(\mathrm{n}=5)$ \\
\hline Males/females & $2 / 6$ & $2 / 3$ \\
\hline Age $^{\mathrm{a}}$, years & $63(33-76)$ & $30(23-38)$ \\
\hline Current smokers & 0 & 0 \\
\hline Ex-smokers & 0 & 0 \\
\hline Inhaled GCS, yes/no & 0 & $5 / 0$ \\
\hline Oral GCS, yes/no & 0 & $3 / 2$ \\
\hline$\beta_{2}$-Agonist, yes/no & 0 & $5 / 0$ \\
\hline \multicolumn{3}{|l|}{ Lung function } \\
\hline $\mathrm{FEV}_{1} \%$ of predicted ${ }^{\mathrm{a}}$ & $110(82-141)$ & $31(22-45)$ \\
\hline $\mathrm{FEV}_{1} /(\mathrm{F}) \mathrm{VC}^{\mathrm{a}}$ & $86(66-121)$ & $50(33-84)$ \\
\hline VC $\%$ of predicted ${ }^{\mathrm{a}}$ & $104(82-126)$ & $54(46-70)$ \\
\hline TLC $\%$ of predicted ${ }^{\mathrm{a}}$ & ND & $104(79-129)$ \\
\hline RV \% of predicted ${ }^{\mathrm{a}}$ & ND & $215(113-318)$ \\
\hline Percent TLCO SB & ND & $60(50-71)$ \\
\hline
\end{tabular}

GCS = Glucocorticosteroid; $\mathrm{FEV}_{1}=$ forced expiratory volume in $1 \mathrm{~s}$; $\mathrm{VC}=$ vital capacity; TLC = total lung capacity; $\mathrm{RV}=$ residual volume; TLCO = diffusing capacity for carbon monoxide.

a Mean (range).

tion of MIG/CXCL9 (fig. 1; table 1). Disrupted neutrophils and mucus were seen in the airway lumen (fig. 1a). Immunogold localization of MIG/CXCL9 revealed presence on the surface of bronchial epithelial cells and on the surface of cilia (fig. 1b). In small airways (i.e. bronchioli), MIG/CXCL9 was detected on the surface of epithelial cells (fig. 1c) as well as in vesicles present in the cytoplasm (fig. 1c), the latter suggesting pinocytosis or export of newly synthesized protein. Weak labeling, corresponding to low amounts of MIG/CXCL9 was detected in the alveoli (fig. 1d). In addition, MIG/CXCL9 was also seen in the airway mucus (fig. 1e). Replacement of the primary antibodies with preimmune IgG resulted in loss of labeling (fig. 1f, g).

MIG/CXCL9 was quantified in sputum of CF patients and healthy controls using ELISA. These measurements showed MIG/CXCL9 at a mean concentration of 1,274 $\mathrm{pg} / \mathrm{ml}$ (range: $1,107-1,646 \mathrm{pg} / \mathrm{ml} ; \mathrm{n}=4$ ) in sputum of CF patients and at a mean concentration of $136 \mathrm{pg} / \mathrm{ml}$ (range $91-221 \mathrm{pg} / \mathrm{ml} ; \mathrm{n}=3$ ) in induced sputum of healthy controls $(\mathrm{p}=0.001)$.

\section{Bactericidal Activity of MIG/CXCL9 against \\ P. aeruginosa}

Using a viable counts assay, recombinant human MIG/ CXCL9 showed a dose-dependent bactericidal activity against $P$. aeruginosa (fig. 2). Salt may influence the activity of HDPs, and different strains may have different pro- tective mechanisms against these proteins, e.g. production of alginate and efflux pumps [11]. MIG/CXCL9 showed strong antibacterial activity against the $P$. aeruginosa strain PA01 and the clinical CF strains 022A, 032, and 195B (fig. 2). However, some clinical $P$. aeruginosa strains isolated from $\mathrm{CF}$ patients were less sensitive to killing by MIG/CXCL9 (strains 041E and 308B). At lower concentrations, the antibacterial activity of MIG/CXCL9 was sometimes impaired in the presence of sodium chloride ( 80 and $160 \mathrm{mM}$, respectively). This was pronounced for the most resistant $P$. aeruginosa strain 308B (fig. $2 \mathrm{~g}$ ). The classical antibacterial peptide LL-37 showed a slightly lower bactericidal activity that also was more affected by the presence of salt compared with MIG/CXCL9 against the P. aeruginosa strain PA01 (fig. 2b). MIG/ CXCL9 showed no cytotoxicity against the bronchial epithelial cell line BEAS-2B (bronchial epithelial cells) in this range of concentrations for $16 \mathrm{~h}$, as indicated by an absence of lactate dehydrogenase release (data not shown).

To investigate if bactericidal concentrations of MIG/ CXCL9 can be reached in the ASL where the depth of the periciliary liquid has been estimated to be approximately $5 \mu \mathrm{m}$, normal bronchial epithelial cells were cultured in an air liquid interface system [13]. After incubation with interferon- $\gamma(100 \mathrm{U} / \mathrm{ml})$ for $24 \mathrm{~h}$, the surface was rinsed with PBS and the MIG/CXCL9 concentration determined by ELISA. Relating to an estimated volume of the periciliary layer, MIG/CXCL9-concentration was in the order of $0.3 \mu \mathrm{M}$, i.e. a bactericidal concentration.

\section{Effects from Salt and $p H$ on the Bactericidal Activity of MIG/CXCL9}

Recently, it was demonstrated, using a porcine model of CF, that the ASL of mutant animals lacking the CFTR gene $\left(\mathrm{CFTR}^{-/-}\right)$had a lower $\mathrm{pH}$ than that of wildtype animals [14]. Thus, the bactericidal properties of MIG/CXCL9 were investigated at reduced $\mathrm{pH}$ in combination with different salt concentrations using the viable counts assay. A small but statistically significant reduction of bacterial killing was observed at increased sodium chloride concentrations but not at low $\mathrm{pH}$ (fig. 3).

\section{Morphology of $P$. aeruginosa after Incubation with MIG/CXCL9}

The P. aeruginosa strains PA01, 041E, 195B, and 308B were grown to mid-logarithmic phase, and thereafter incubated with MIG/CXCL9 $(1 \mu \mathrm{M})$ or in buffer alone for $1 \mathrm{~h}$ at $37^{\circ} \mathrm{C}$. The samples were processed for SEM and in 

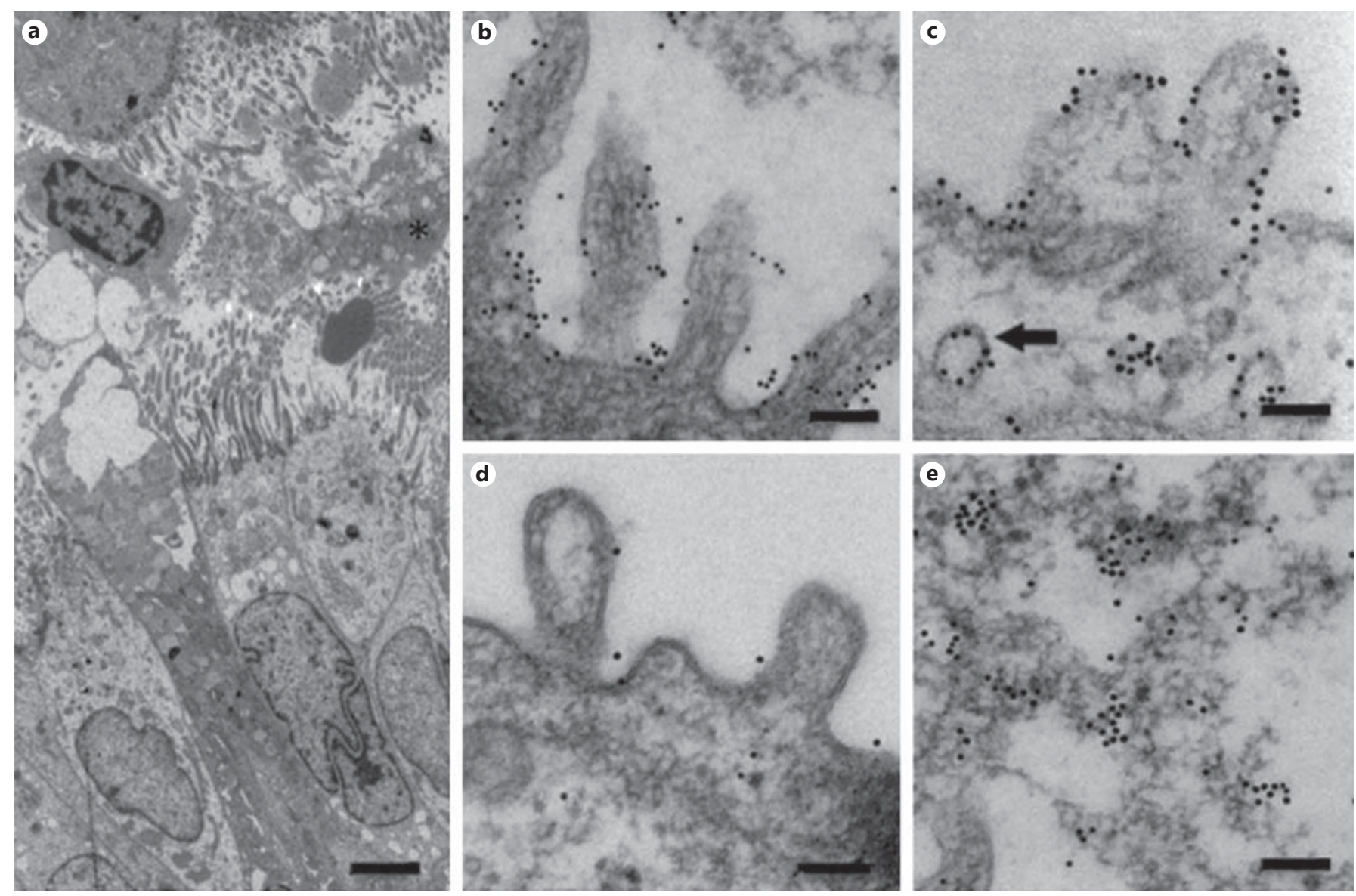

Fig. 1. The distribution of MIG/CXCL9 in CF lung tissue as detected by immunoelectron microscopy. Ultrathin sections from CF lung specimens were incubated with specific antibodies against MIG/CXCL9. Bound antibodies were visualized using secondary goat anti-rabbit antibodies conjugated with colloidal gold particles $(10 \mathrm{~nm})$. a In large airways, ciliated epithelium and goblet cells outline the lumen that shows presence of necrotic and disrupted neutrophils and mucus. b MIG/CXCL9 is detected on the surface of bronchial epithelial cells and on cilia as reflected by immunogold particles. $\mathbf{c}$ In small airways (i.e. bronchioli), a similar distribution of MIG/CXCL9 is observed with the presence on the surface of epithelial cells as well as in vesicles present in the cytoplasm (arrow). The latter may represent pinocytosis or export of de novo synthesized MIG/ CXCL9. d Only low levels of MIG/CXCL9 were detected in alveoli as visualized by scant colloidal gold particles. e Presence of MIG/CXCL9 was also seen in airway mucus. f, $\mathbf{g}$ Replacement of the primary antibodies with preimmune IgG resulted in loss of labeling. The bars represent $1 \mu \mathrm{m}(\mathbf{a}), 250 \mathrm{~nm}(\mathbf{b}, \mathbf{d}, \mathbf{f}, \mathbf{g})$, and $100 \mathrm{~nm}(\mathbf{c}, \mathbf{e})$.

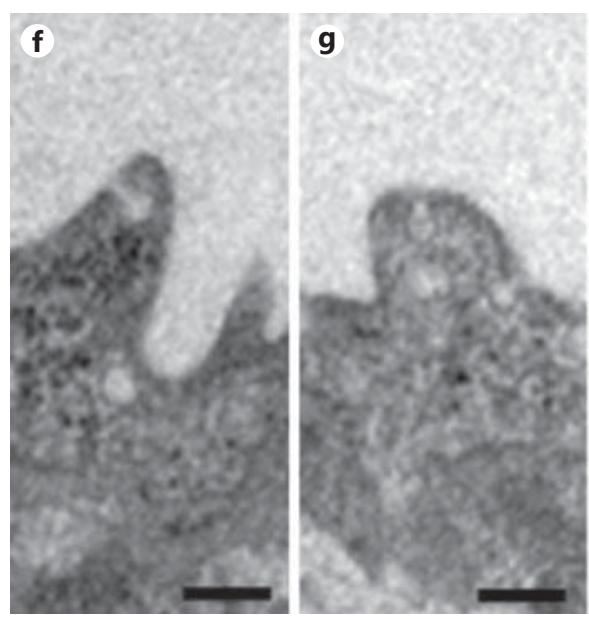

Fig. 2. Bactericidal activity of MIG/CXCL9 against $P$. aeruginosa and the effect of salt. $P$. aeruginosa (the laboratory strain PA01 and the strains isolated from airways of CF patients: 022A, 032, 041E, $195 \mathrm{~B}$, and 308B) were grown to mid-logarithmic phase and incubated with the indicated concentrations of MIG/CXCL9, LL-37, or in buffer alone in the absence or presence of sodium chloride $(80$ and $160 \mathrm{mM}$, respectively) for $1 \mathrm{~h}$ at $37^{\circ} \mathrm{C}$. To assess the antibacterial activity, the number of bacterial colonies after MIG/CXCL9 or LL37 incubation was compared with the number of bacterial colo- nies obtained after incubation in buffer alone and is expressed as percent bacterial killing. The antibacterial activity of MIG/CXCL9 and LL-37 against $P$. aeruginosa strains PA01 (a, b), 022A (c), 032 (d), 041E (e), 195B (f) and 308B (g) are shown. The data represent the mean \pm SD from 4 to 15 separate experiments. Both MIG/ CXCL9 and LL-37 increased bacterial killing of all bacterial strains in a concentration-dependent manner $(\mathrm{p}<0.001)$. Statistical analysis was performed using two-way ANOVA followed by Tukey's multiple comparison test. ${ }^{*} \mathrm{p}<0.05$; $^{* *} \mathrm{p}<0.01$; $^{* * *} \mathrm{p}<0.001$.

(For figure see next page.) 


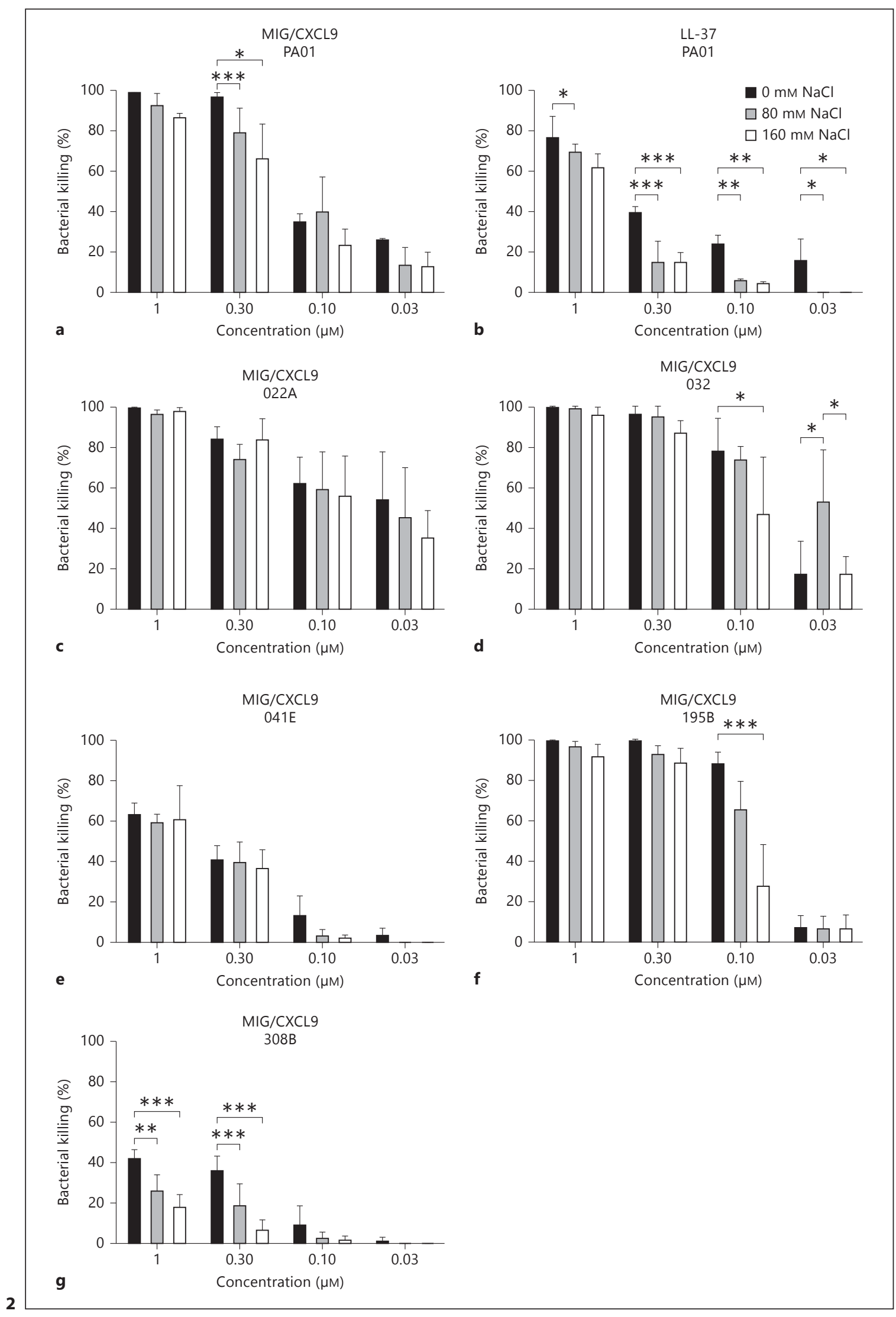




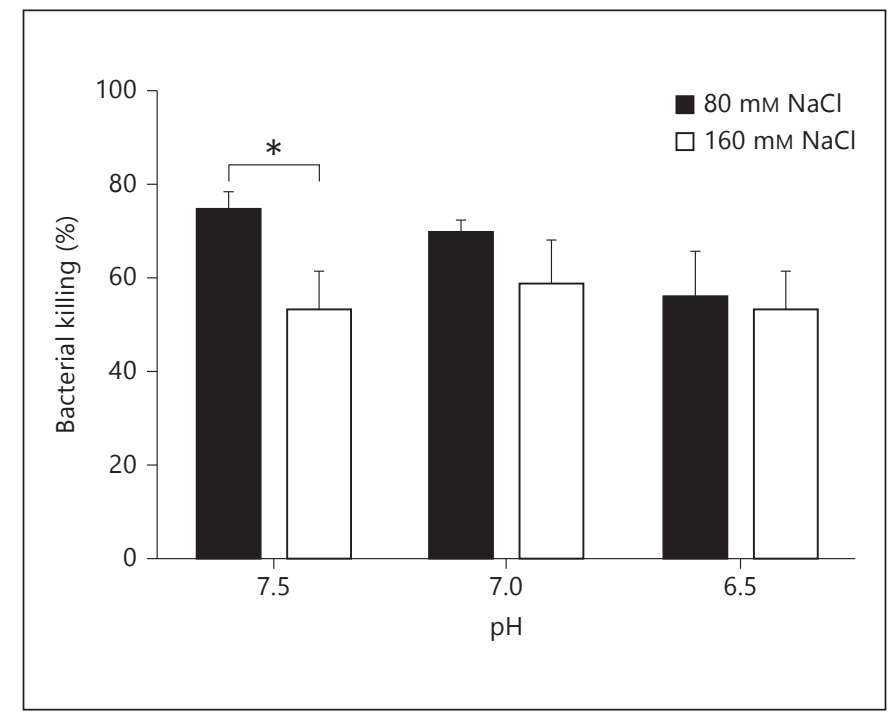

Fig. 3. Effects from salt and $\mathrm{pH}$ on the bactericidal activity of MIG/CXCL9. P. aeruginosa (strain PA01) was incubated with MIG/CXCL9 $(0.3 \mu \mathrm{M})$ at the indicated $\mathrm{pH}$ and sodium chloride concentrations for $1 \mathrm{~h}$, and thereafter investigated for bactericidal activity using the viable counts assay. A small but significant reduction of bacterial killing was observed at increased sodium chloride concentrations. The data shown represent the mean \pm $\mathrm{SD}$ of 3 separate experiments. Statistical analysis was performed using two-way ANOVA followed by Tukey's multiple comparison test. ${ }^{*} \mathrm{p}<0.05$.

parallel viable counts were performed to confirm bacterial killing. SEM revealed that interaction with MIG/ CXCL9 caused blebs and leakage of intracellular contents in all $P$. aeruginosa strains investigated except for the strain $308 \mathrm{~B}$ that remained mainly intact (fig. 4). This corresponds to the findings using viable counts where strain $308 \mathrm{~B}$ was less vulnerable to the bactericidal effects of MIG/CXCL9 (fig. 2). Bacteria in buffer alone served as controls, showing an intact morphology.

\section{A Cleaved Form of MIG/CXCL9 Is Found in CF Sputum}

Western blot was performed to investigate whether MIG/CXCL9 was present in CF sputum and in induced sputum obtained from healthy controls. Recombinant human MIG/CXCL9 was used as a control and appeared as a single band. In CF sputum, bands corresponding to the MIG/CXCL9 full-length protein, a smaller cleaved fragment, as well as bands of higher molecular weight, suggesting oligomerization or binding to other molecules, were detected (fig. 5a). In induced sputum from healthy controls, the band corresponding to the MIG/
CXCL9 full-length protein was seen, and faint bands corresponding to oligomers (fig. 5b). In vitro, elastase of $P$. aeruginosa produced a fragment of a size corresponding to that observed in CF sputum (fig. 5c). In contrast, the serine-proteases of neutrophils (i.e. elastase, cathep$\sin \mathrm{G}$, and proteinase 3 ) generated a major fragment that was smaller in size (around $6 \mathrm{kDa}$ ) compared with the major fragment generated by elastase of $P$. aeruginosa (online suppl. fig. 1; for all online suppl. material, see www.karger.com/doi/10.1159/000365399).

Interestingly, the related chemokine IP-10/CXCL10 was resistant to cleavage by elastase of $P$. aeruginosa, while I-TAC/CXCL11 was completely degraded (fig. $5 \mathrm{~d}$ ). This is interesting since I-TAC/CXCL11 has a higher chemotactic activity compared with MIG/CXCL9 and IP-10/CXCL10, further underlining that the elastase activity results in impaired recruitment of CXCR3-bearing cells [27].

\section{Characterization of Fragments Generated by Elastase} of $P$. aeruginosa

The MIG/CXCL9 fragments generated by elastase of $P$. aeruginosa, were characterized by $\mathrm{N}$-terminal sequencing and MS/MS. The largest fragment, corresponding to the size seen on Western blot was 66 amino acids long (IST-66) and derived from the mid-portion of MIG/ CXCL9. In addition, one slightly smaller (IST-51) and one substantially smaller fragment (LIKK-15) were identified (fig. 5e). The MIG/CXCL9 fragments generated by elastase of $P$. aeruginosa were synthesized and used in a viability counts assay against $P$. aeruginosa (strain PA01). The bactericidal activities of these peptides, IST-66, IST51 and LIKK-15 respectively, were approximately 50\% lower compared to that of the MIG/CXCL9 full-length protein (fig. 5f).

The MIG/CXCL9-Fragments Prevent Activation of the CXCR3 Receptor

In addition to MIG/CXCL9, IP-10/CXCL10 and ITAC/CXCL11 bind and activate the CXCR3-receptor [28]. First, the MIG/CXCL9-derived fragments IST-66, IST-51 and LIKK-15 were investigated for calcium-mobilizing properties using a murine cell line transfected with the human CXCR3 receptor. MIG/CXCL9 induced a dose-dependent calcium-mobilization with a maximum response at $100 \mathrm{nM}$, whereas the fragments IST-66, IST-51 and LIKK-15 did not at corresponding concentrations (fig. 6a). However, when MIG/CXCL9 (100 nM) was preincubated with the fragments IST-66 (100 nM), IST-51 (100 nM) or LIKK-15 (100 nM) respectively, reduced calcium mobilization was observed compared to that caused 
Fig. 4. Morphology of $P$. aeruginosa after incubation with MIG/CXCL9. The P. aeruginosa strains PA01, 195B, 041E and 308B were grown to mid-logarithmic phase and thereafter incubated with MIG/CXCL9 $(1 \mu \mathrm{M})$ or in buffer alone for $1 \mathrm{~h}$ at $37^{\circ} \mathrm{C}$. The samples were processed for SEM and in parallel viable counts were performed to confirm bacterial killing. The $P$. aeruginosa strains PA01, 195B, 041E and 308B in buffer alone $(\mathbf{a}, \mathbf{c}, \mathbf{e}, \mathbf{g})$ are intact, while the interaction with MIG/CXCL9 caused blebs and leakage of intracellular contents in all $P$. aeruginosa strains (PA01, 195B, 041E; b, d, f) investigated, except for the strain $308 \mathrm{~B}$ that remained mainly intact (h). This corresponds to the findings using viable counts where strain $308 \mathrm{~B}$ was less vulnerable to the bactericidal effects of MIG/ CXCL9 (fig. 2). Bacteria in buffer alone served as controls, showing an intact morphology. The bar represents $1 \mu \mathrm{m}$.
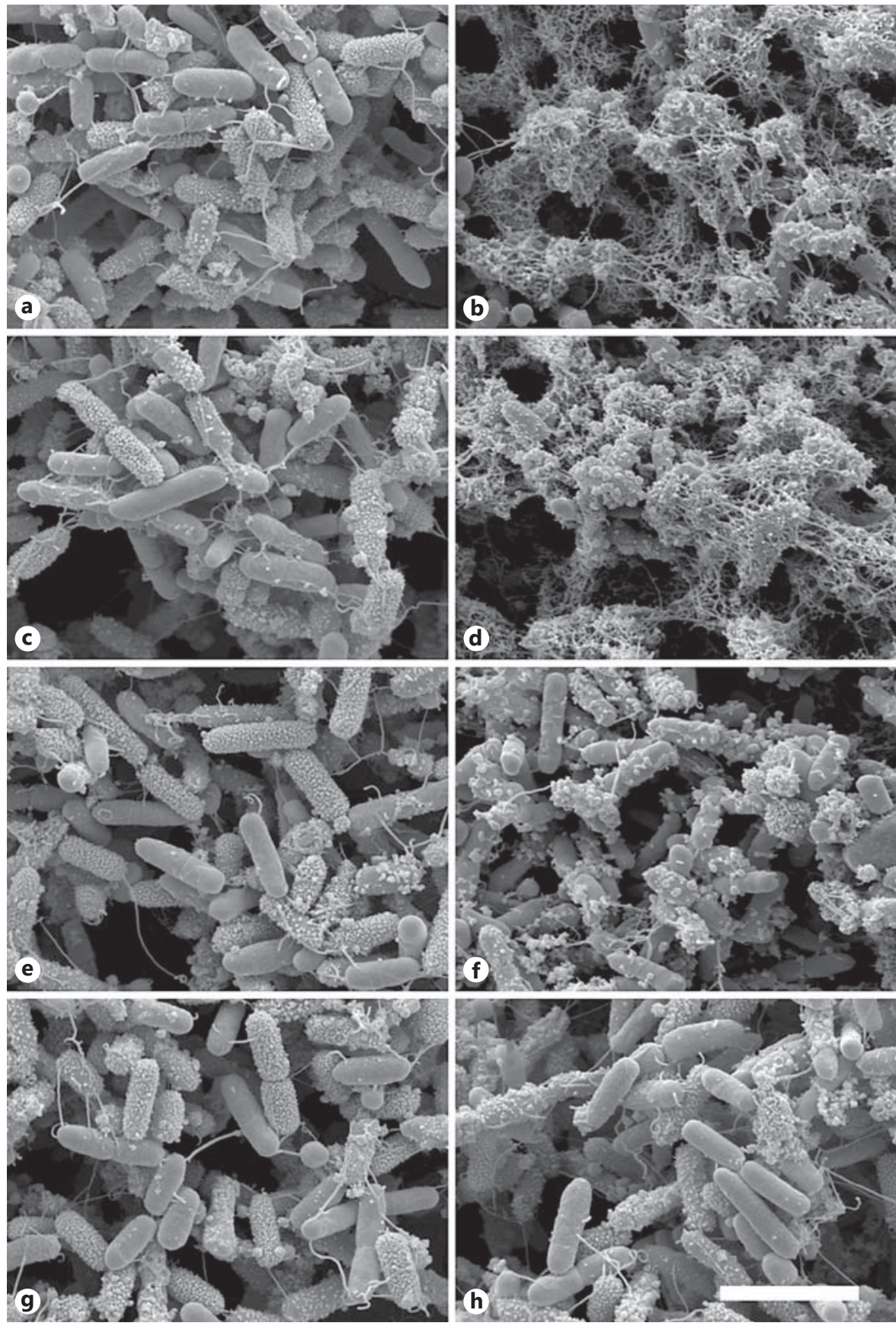

by MIG/CXCL9 alone (fig. 6b). IP-10/CXCL10 and ITAC/CXCL11 also induced dose-dependent calcium mobilization with a maximum response at $100 \mathrm{nM}$, but when preincubated with the fragments IST-66 (100 nM), IST-51 (100 nM) or LIKK-15 (100 nM), no calcium-mobilization was observed (fig. 6c, d). Scatchard analysis of IST-66 revealed noncompetitive interactions (data not shown).

MIG/CXCL9 in Cystic Fibrosis

\section{CXCR3-Expressing Cells in CF and Lung Tissue of}

Controls

To investigate if there is a decreased recruitment of CXCR3-bearing cells in CF that may reflect actions from the fragments described above, tissue samples from CF lung explants and control tissue from previously healthy individuals were analyzed using immunohistochemistry (fig. 7). In lung tissue of both CF and controls, CXCR3-

J Innate Immun 2014;6:846-859 
Fig. 5. MIG/CXCL9 is processed in CF airways and cleaved by elastase of $P$. aeruginosa in vitro. a, b In sputum from CF patients colonized with $P$. aeruginosa and healthy controls, respectively, the MIG/ CXCL9 full-length protein was detected by Western blot (arrows). In addition, a fragment of MIG/CXCL9 could be visualized in CF sputum (arrowhead) but not in healthy controls. c In vitro, the elastase of $P$. aeruginosa produced a fragment of similar size as in CF sputum. d Interestingly, the related chemokine IP-10/CXCL10 was resistant to cleavage by the elastase of $P$. aeruginosa, while I-TAC/CXCL11 was completely degraded. The obtained fragment in c was further analyzed by N-terminal sequencing and mass spectrometry, and three peptides, IST-66, IST51 and LIKK15 , were found (e). The three peptides were synthesized and used in a viability assay against $P$. aeruginosa (strain PA01).

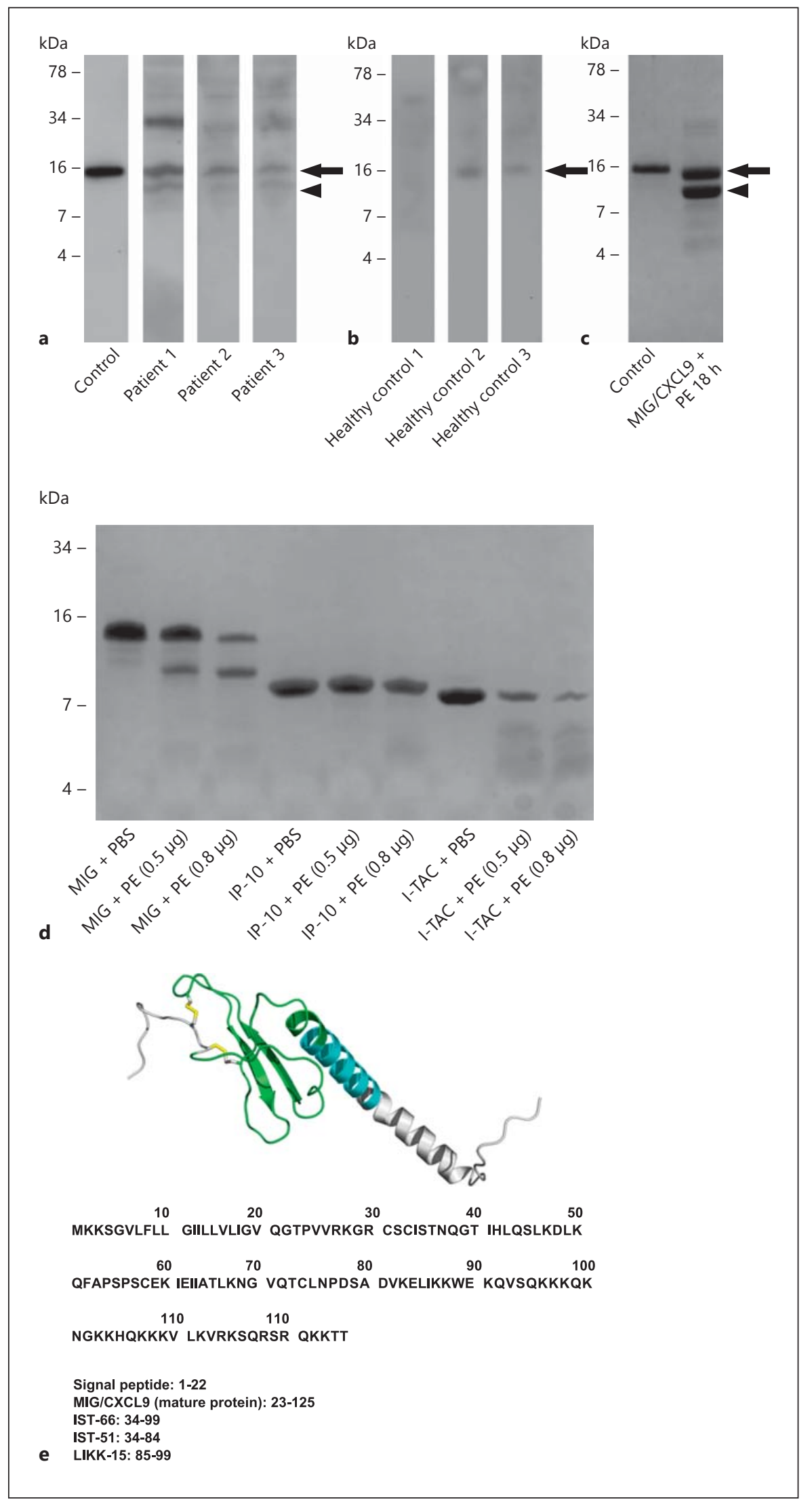


Fig. 5. MIG/CXCL9 is processed in CF airways and cleaved by elastase of $P$. aeruginos $a$ in vitro. $\mathbf{f}$ The bactericidal activity of these peptides was compared with the antibacterial activity of the MIG/CXCL9 fulllength protein using a viable counts assay. The fragments displayed a bactericidal activity being less than $50 \%$ of the holoprotein. The data shown $(\mathbf{a}-\mathbf{d}, \mathbf{f})$ represent mean \pm SD from 3 separate experiments. Statistical analysis was performed using two-way ANOVA followed by Tukey's multiple comparison test. ${ }^{* * *} \mathrm{p}<0.001$.

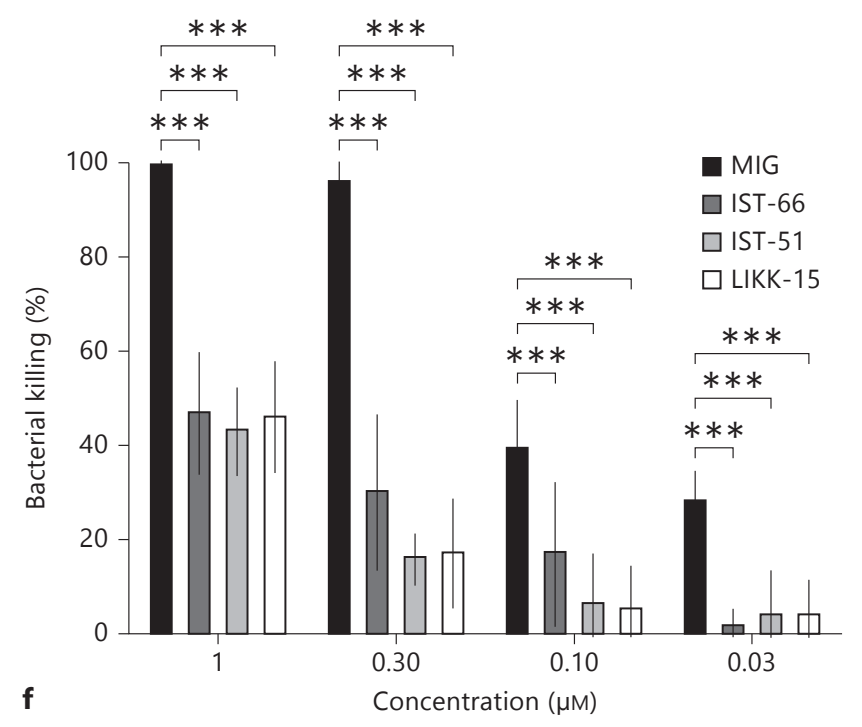

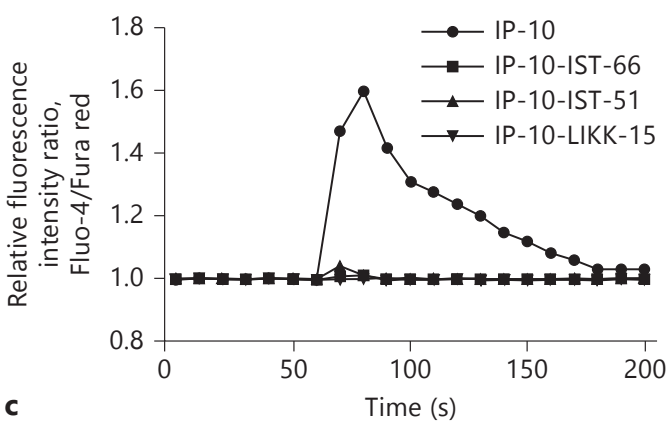

Fig. 6. The MIG/CXCL9-derived fragments inhibit CXCR3-activation by MIG/CXCL9, IP-10/CXCL10, and I-TAC/CXCL11. MIG/CXCL9 IP-10/CXCL10, I-TAC/CXCL11, and the MIG/ CXCL9-derived fragments IST-66, IST-51 and LIKK-15 were investigated for their calcium-mobilizing properties in CXCR3transfected cells. a MIG/CXCL9 (100 nM) induced calcium-mobilization, whereas the fragments IST-66, IST-51 and LIKK-15 did not (all at $100 \mathrm{nM})$. b When MIG/CXCL9 (100 nM) was preincu-
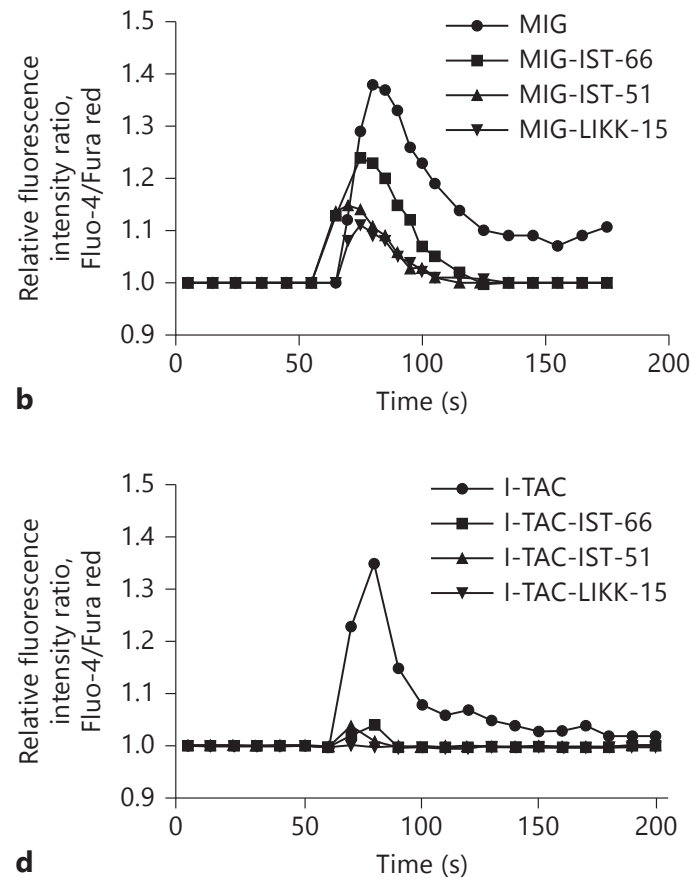

bated with the fragments IST-66, IST-51 and LIKK-15, respectively (all at $100 \mathrm{nM}$ ), the MIG/CXCL9-induced calcium mobilization was inhibited. In the case of IP-10/CXCL10 (100 nM; c) and I-TAC/CXCL11 (100 nM; d), preincubation with the fragments IST-66 (100 nM), IST-51 (100 nM) and LIKK-15 (100 nM), respectively, abolished the calcium immobilization. Three to 6 separate experiments were performed, and one representative from each condition is shown. 

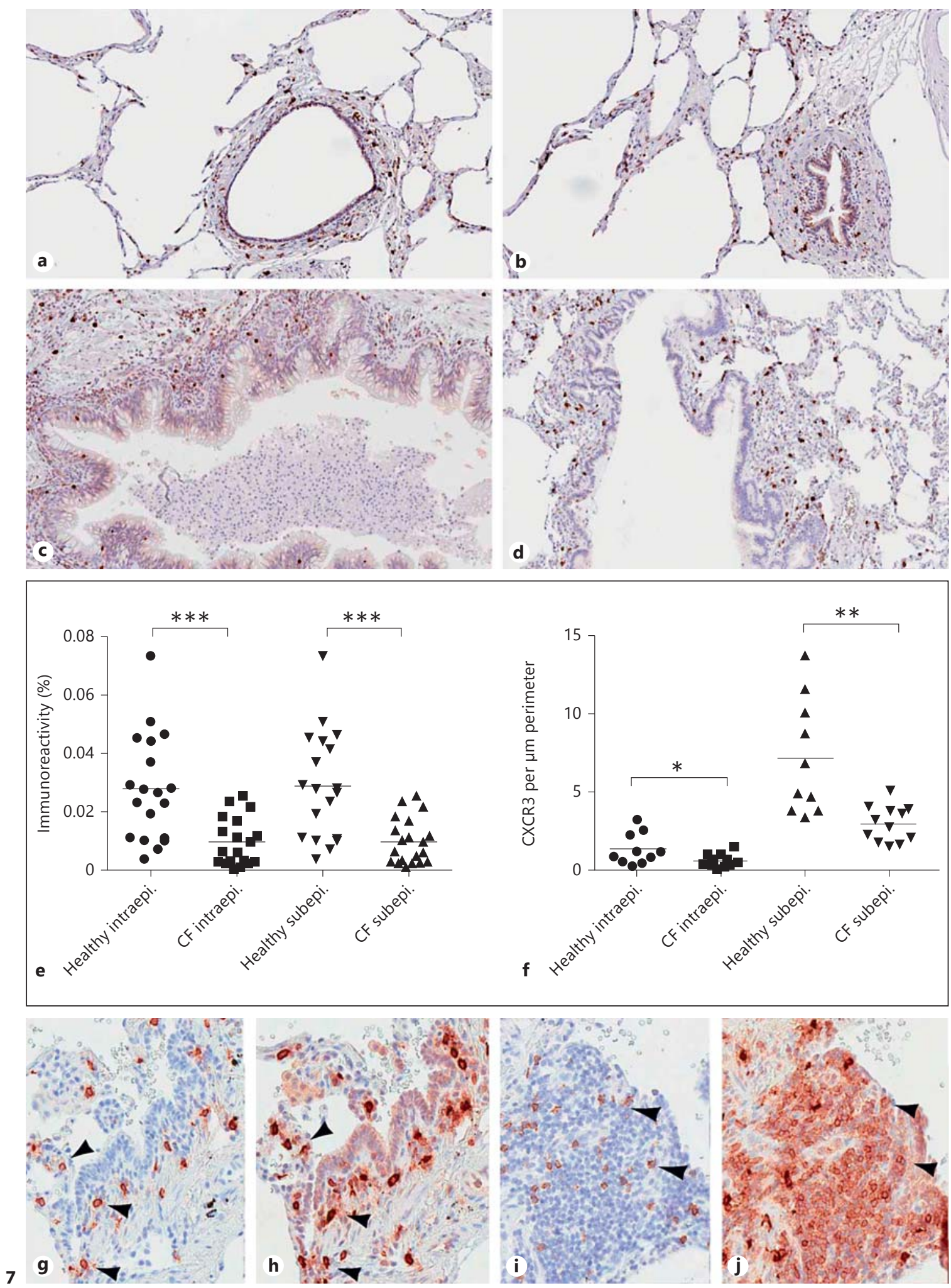

(For legend see next page.) 
expressing cells were present in the walls of the small airways (fig. $7 \mathrm{a}-\mathrm{d}, \mathrm{g}-\mathrm{j}$ ). A quantitative analysis showed significantly fewer CXCR3-expressing cells both within the epithelium and in the subepithelial tissue of CF patients (fig. 7e, f). Instead, abundant CXCR3-expressing cells were found in the expanded germinal centers of the extended CF lung lymphoid tissue. Phenotypic characterization of CXCR3-expressing cells was performed by immunohistochemical staining using serial sections. First, mast cells were identified by colocalization of tryptase (fig. 7g) and CXCR3 (fig. 7h) on parallel sections. Next, CD8+ T cells were visualized by CD57 (fig. 7i) and CXCR3 (fig. 7j) on parallel sections. Taken together, the number of mast cells and CD8+ T cells was reduced in the small airways of CF patients compared with control tissue.

\section{Discussion}

In this study, we show that MIG/CXCL9 expressed in the airways of CF patients can be processed by elastase of $P$. aeruginosa, resulting in fragments having impaired bactericidal activity and also serving as noncompetitive antagonists of the CXCR3 receptor. In vivo, we found an increased number of CXCR3-bearing cells in the germinal centers of CF lung but a paradoxical low number of such cells in the vicinity of airway epithelium compared with lung tissue of controls. The latter suggesting that the processing of MIG/ CXCL9 has an impact on recruitment of CXCR3-bearing cells (i.e. NK cells, cytotoxic T cells, and mast cells), also contributing to impaired airway immunity in CF.

MIG/CXCL9 showed a dose-dependent bactericidal activity against $P$. aeruginosa that was, to a small degree, affected by increased salt concentrations and a reduced $\mathrm{pH}$. The altered properties of ASL in CF have been subject to much debate, both with respect to its depth and whether the salt concentration is increased compared with healthy airways [7-10, 13]. The activity of many HDPs is impaired by high salt concentrations (e.g. hBD-2 and hBD-3) $[11,12]$. However, recently it was demonstrated

Fig. 7. CXCR3-expressing cells in lungs from CF patients and control subjects. Small airways and alveoli were investigated for the presence of CXCR3-expressing cells. In lungs of controls (a, b), CXCR3+ cells are present in the walls of the small airways, which is also the case in CF lungs (c, $\mathbf{d}, \mathbf{g}-\mathbf{j})$. e, $\mathbf{f}$ Using morphometric analysis, fewer CXCR3+ cells were found both intra- and subepithelially. Instead, abundant CXCR3+ cells were foremost localized to the germinal centers in the CF lungs. Phenotypic characterization of CXCR3 + cells was performed by immunohis- in a porcine model of $\mathrm{CF}\left(\mathrm{CFTR}^{-/-}\right)$that the $\mathrm{pH}$ was lowered in the ASL of these animals, resulting in impaired antibacterial activity of lysozyme and lactoferrin and that the activity was restored upon neutralization of the $\mathrm{pH}$ [14]. Thus, protonation of the bacterial membrane at a lower $\mathrm{pH}$ is likely to reduce the attraction between HDPs and the bacterial plasma membrane, resulting in reduced antibacterial activity [29]. It is thus interesting that MIG/ CXCL9 retain most of its bactericidal activity at low $\mathrm{pH}$ and also in the presence of high salt concentrations.

Lysozyme, lactoferrin, and SLPI are constitutively expressed and present at relatively high levels in the ASL and likely to be an important part of airway innate immunity [4]. How important is MIG/CXCL9 in this context? Both in a previous and the current study (using an air liquid interface cell culture model), we were able to demonstrate significant bactericidal concentrations of MIG/CXCL9 released by airway epithelial cells after stimulation with interferon- $\gamma$ [19]. The immunoelectron microscopic depiction in this study, showing MIG/ CXCL9 associated with the surface of airway epithelial cells suggests presence in the ASL in vivo, in addition to being present in mucus, being less likely to exert biological functions in the latter case. In addition, MIG/ CXCL9 may bind to glycosaminoglycans (GAGs) on the epithelial cell surface. Such binding together with the oligomerizing properties of this molecule can be a way to retain an antibacterial gradient at the epithelial cell surface.

It is possible that MIG/CXCL9 is processed by elastase of $P$. aeruginosa in vivo, since a smaller fragment of the full-length protein was detected in sputum of CF patients colonized by these bacteria, while only intact MIG/ CXCL9 was found in sputum from healthy subjects. A fragment of similar size was obtained after digestion of the MIG/CXCL9 full-length protein using elastase of $P$. aeruginosa, supporting the finding. The fragments generated are derived from the proximal part of the putative a-helix. The C-terminal region, having cationic and amphipathic properties, is proposed to possess the antibacte-

tochemical staining using serial sections. First, mast cells were identified by tryptase (g) followed by CXCR3 (h) on a parallel section. Next, CD8+ T cells were visualized by CD57 (i) followed by CXCR3 (j) on a parallel section. Arrowheads denote identical cells. The experiments were performed on CF lung tissue obtained from 5 individuals and control tissue obtained from 8 individuals. Mann-Whitney's U test for unpaired samples was used for comparison between the groups. ${ }^{*} \mathrm{p}<0.05$; $^{* *} \mathrm{p}<0.01$; ${ }^{* * *} \mathrm{p}<$ 0.001 . 
rial activity, while the $\mathrm{N}$-terminal harbors the receptoractivating properties [30-32]. This correlates well with our results, i.e. that the fragments have less bactericidal activity and no receptor-activating properties. Also, this might be the case for many other chemokines and HDP. However, it could not be ruled out that other proteases, for example the serine proteases of neutrophils (i.e. elastase, cathepsin G, and proteinase 3 ) released by the abundant neutrophils present in the disease are involved in fragmentation of MIG/CXCL9 (online suppl. fig. 1) [27]. IP-10/CXCL10 and I-TAC/CXCL11 were also subjected to elastase of $P$. aeruginosa, IP-10/CXCL10 was resistant to degradation while I-TAC/CXCL11 was highly degraded, resulting in multiple but no distinct fragments (fig. 5d). Consequently, it appears unlikely that elastase of $P$. aeruginosa generates fragments from IP-10/CXCL10 and I-TAC/CXCL11 that would inhibit downstream CXCR3 signaling.

There is a mixed Th1 and Th2 inflammation in CF where MIG/CXCL9 is expressed [5]. However, P. aerugino$s a$-infected patients with CF had significantly higher levels of Th2-polarized cells, IL-4, IL-13, and TARC and lower levels of interferon $-\gamma$ compared with noninfected patients with $\mathrm{CF}$ and healthy controls, suggesting that the bacteria skew inflammation to promote their survival $[5,6]$.

Does the impaired recruitment of CXCR3-bearing cells contribute to the longstanding colonization with $P$. aeruginosa in $\mathrm{CF}$ ? NKT cells do play a role in clearing microorganisms, including $P$. aeruginosa from the airways [33]. In mice models, mast cells played an important role against airway infection and were crucial for the induc- tion of protective innate immune responses to bacterial skin infections $[34,35]$. Interestingly, in a study showing increased levels of all three CXCR3-activating chemokines (i.e. MIG/CXCL9, IP10/CXCL10, and I-TAC/ CXCL11) in BAL fluid of CF patients (both with and without colonization with $P$. aeruginosa), no increase in the number of CXCR3-positive T cells was detected, supporting the findings of the current study [5].

In conclusion, MIG/CXCL9 expressed in CF lungs can be processed by elastase of $P$. aeruginosa, impairing its bactericidal properties and counteracting its function as a chemokine, recruiting CXCR3-bearing cells, contributing to the compromised airway host defense seen in CF.

\section{Acknowledgements}

We are grateful to Pia Andersson and Maria Baumgarten for skillful technical assistance and Dr. Lena M. Svensson and Dr. Mohammad Kadivar for help with flow cytometry analysis.

This work was supported by the Swedish Research Council (project No. 4224 and 7480), the Swedish Heart and Lung Foundation (No. 20100164), the Medical Faculty of Lund University, Swedish Government Funds for Clinical Research, Swedish Foundation for Strategic Research, and the foundations of Bergh, Greta and Johan Kock, and Alfred Österlund.

\section{Disclosure Statement}

All authors declare that they have no financial or personal relationships with other people or organizations that have influenced the present study.

\section{References}

1 O'Sullivan BP, Freedman SD: Cystic fibrosis. Lancet 2009;373:1891-1904.

-2 Hartl D, Gaggar A, Bruscia E, Hector A, Mar$\cos$ V, Jung A, Greene C, McElvaney G, Mall $M$, Doring G: Innate immunity in cystic fibrosis lung disease. J Cyst Fibros 2012;11:363382.

3 Mariencheck WI, Alcorn JF, Palmer SM, Wright JR: Pseudomonas aeruginosa elastase degrades surfactant proteins A and D. Am J Respir Cell Mol Biol 2003;28:528-537.

-4 Singh PK, Tack BF, McCray PB Jr, Welsh MJ: Synergistic and additive killing by antimicrobial factors found in human airway surface liquid. Am J Physiol Lung Cell Mol Physiol 2000;279:L799-L805.

5 Hartl D, Griese M, Kappler M, Zissel G, Reinhardt D, Rebhan C, Schendel DJ, KraussEtschmann S: Pulmonary $\mathrm{T}(\mathrm{H}) 2$ response in Pseudomonas aeruginosa-infected patients with cystic fibrosis. J Allergy Clin Immunol 2006;117:204-211.

6 Tiringer K, Treis A, Fucik P, Gona M, Gruber S, Renner S, Dehlink E, Nachbaur E, Horak F, Jaksch P, et al: A Th17- and Th2-skewed cytokine profile in cystic fibrosis lungs represents a potential risk factor for Pseudomonas aeruginosa infection. Am J Respir Crit Care Med 2013;187:621-629.

7 Smith JJ, Travis SM, Greenberg EP, Welsh MJ: Cystic fibrosis airway epithelia fail to kill bacteria because of abnormal airway surface fluid. Cell 1996;85:229-236.

-8 Joris L, Dab I, Quinton PM: Elemental composition of human airway surface fluid in healthy and diseased airways. Am Rev Respir Dis 1993;148:1633-1637.

-9 Matsui H, Grubb BR, Tarran R, Randell SH, Gatzy JT, Davis CW, Boucher RC: Evidence for periciliary liquid layer depletion, not abnormal ion composition, in the pathogenesis of cystic fibrosis airways disease. Cell 1998;95:1005-1015.

10 Guggino WB: Cystic fibrosis and the salt controversy. Cell 1999;96:607-610.

11 Goldman MJ, Anderson GM, Stolzenberg ED, Kari UP, Zasloff M, Wilson JM: Human beta-defensin- 1 is a salt-sensitive antibiotic in lung that is inactivated in cystic fibrosis. Cell 1997;88:553-560.

12 Bals R, Wang X, Wu Z, Freeman T, Bafna V, Zasloff M, Wilson JM: Human beta-defensin 2 is a salt-sensitive peptide antibiotic expressed in human lung. J Clin Invest 1998; 102:874-880.

13 Chen JH, Stoltz DA, Karp PH, Ernst SE, Pezzulo AA, Moninger TO, Rector MV, Reznikov LR, Launspach JL, Chaloner K, et al: Loss of anion transport without increased sodium absorption characterizes newborn porcine cystic fibrosis airway epithelia. Cell 2010;143:911-923. 
14 Pezzulo AA, Tang XX, Hoegger MJ, Alaiwa $\mathrm{MH}$, Ramachandran S, Moninger TO, Karp PH, Wohlford-Lenane CL, Haagsman HP, vanEijk $\mathrm{M}$, et al: Reduced airway surface $\mathrm{pH}$ impairs bacterial killing in the porcine cystic fibrosis lung. Nature 2012;487:109-113.

$\checkmark 15$ Coakley RD, Grubb BR, Paradiso AM, Gatzy JT, Johnson LG, Kreda SM, O'Neal WK, Boucher RC: Abnormal surface liquid $\mathrm{pH}$ regulation by cultured cystic fibrosis bronchial epithelium. Proc Natl Acad Sci USA 2003; 100:16083-16088.

16 Linge HM, Collin M, Giwercman A, Malm J, Bjartell A, Egesten A: The antibacterial chemokine MIG/CXCL9 is constitutively expressed in epithelial cells of the male urogenital tract and is present in seminal plasma. J Interfer Cytok Res 2008;28:191-196.

-17 Cole AM, Ganz T, Liese AM, Burdick MD, Liu L, Strieter RM: IFN-inducible ELR-CXC chemokines display defensin-like antimicrobial activity. J Immunol 2001;167:623-627.

18 Cole KE, Strick CA, Paradis TJ, Ogborne KT, Loetscher M, Gladue RP, Lin W, Boyd JG, Moser B, Wood DE, Sahagan BG, Neote K: Interferon-inducible $\mathrm{T}$ cell alpha chemoattractant (I-TAC): a novel non-ELR CXC chemokine with potent activity on activated $\mathrm{T}$ cells through selective high affinity binding to CXCR3. J Exp Med 1998;187:2009-2021.

$\checkmark 19$ Egesten A, Eliasson M, Johansson HM, Olin AI, Morgelin M, Mueller A, Pease JE, Frick IM, Bjorck L: The CXC chemokine MIG/ CXCL9 is important in innate immunity against Streptococcus pyogenes. J Infect Dis 2007; 195:684-693.

20 Crawford MA, Burdick MD, Glomski IJ, Boyer AE, Barr JR, Mehrad B, Strieter RM, Hughes MA: Interferon-inducible CXC chemokines directly contribute to host defense against inhalational anthrax in a murine model of infection. PLoS Pathog 2010;6:e1001199.
21 Nordin SL, Andersson C, Bjermer L, Bjartell A, Mörgelin M, Egesten A: Midkine is part of the antibacterial activity released at the surface of differentiated bronchial epithelial cells. J Innate Immun 2013;5:519-530.

22 Holloway BW: Genetic recombination in Pseudomonas aeruginosa. J Gen Microbiol 1955;13:572-581.

23 Stover CK, Pham XQ, Erwin AL, Mizoguchi SD, Warrener P, Hickey MJ, Brinkman FS, Hufnagle WO, Kowalik DJ, Lagrou M, et al: Complete genome sequence of Pseudomonas aeruginosa $\mathrm{PAO} 1$, an opportunistic pathogen. Nature 2000;406:959-964.

24 Carlsson M, Shukla S, Petersson AC, Segelmark M, Hellmark T: Pseudomonas aeruginosa in cystic fibrosis: pyocyanin negative strains are associated with BPI-ANCA and progressive lung disease. J Cyst Fibros 2011; 10:265-271.

25 Schwede T, Kopp J, Guex N, Peitsch MC: Swiss-model: an automated protein homology-modeling server. Nucleic Acids Res 2003; 31:3381-3385.

26 Erdjument-Bromage H, Lui M, Sabatini DM, Snyder SH, Tempst P: High-sensitivity sequencing of large proteins: partial structure of the rapamycin-FKBP12 target. Protein Sci 1994;3:2435-2446.

27 Cole KE, Strick CA, Paradis TJ, Ogborne KT, Loetscher M, Gladue RP, Lin W, Boyd JG, Moser B, Wood DE, Sahagan BG, Neote K: Interferon-inducible $\mathrm{T}$ cell chemoattractant (I-TAC): a novel non-ELR CXC chemokine with potent activity on activated $\mathrm{T}$ cells through selective high affinity binding to CXCR3. J Exp Med 1998;187:2009-2021.
28 Clark-Lewis I, Mattioli I, Gong JH, Loetscher P: Structure-function relationship between the human chemokine receptor CXCR3 and its ligands. J Biol Chem 2003; 278:289-295.

29 Nordin SL, Jovic S, Kurut A, Andersson C, Gela A, Bjartell A, Morgelin M, Olin AI, Lund M, Egesten A: High expression of midkine in the airways of patients with cystic fibrosis. Am J Respir Cell Mol Biol 2013;49: 935-942.

30 Clark-Lewis I, Mattioli I, Gong JH, Loetscher P: Structure-function relationship between the human chemokine receptor CXCR3 and its ligands. J Biol Chem 2003; 278:289-295

31 Colvin RA, Campanella GS, Sun J, Luster AD: Intracellular domains of CXCR3 that mediate CXCL9, CXCL10, and CXCL11 function. J Biol Chem 2004;279:30219-30227.

32 Proost P, Schutyser E, Menten P, Struyf S, Wuyts A, Opdenakker G, Detheux M, Parmentier M, Durinx C, Lambeir AM, et al: Amino-terminal truncation of CXCR3 agonists impairs receptor signaling and lymphocyte chemotaxis, while preserving antiangiogenic properties. Blood 2001;98:35543561.

33 Tupin E, Kinjo Y, Kronenberg M: The unique role of natural killer T cells in the response to microorganisms. Nat Rev Microbiol 2007;5: 405-417.

34 Xu X, Zhang D, Lyubynska N, Wolters PJ, Killeen NP, Baluk P, McDonald DM, Hawgood S, Caughey GH: Mast cells protect mice from mycoplasma pneumonia. Am J Respir Crit Care Med 2006;173:219-225.

-35 Siebenhaar F, Syska W, Weller K, Magerl M, Zuberbier T, Metz M, Maurer M: Control of Pseudomonas aeruginosa skin infections in mice is mast cell-dependent. Am J Pathol 2007;170:1910-1916. 